\title{
How many Babinski's signs are there?
}

\author{
Fabio T. Kakitani ${ }^{1}$, Daniel Collares ${ }^{1}$, Adam Y. Kurozawa', \\ Plínio M.G. de Lima², Hélio A.G. Teive ${ }^{3}$
}

\begin{abstract}
In addition to the famous sign described by Joseph Babinski, which is also known as Babinski's reflex, there are references in the literature to various other signs described by this famous disciple of J-M Charcot. This article reviews all the neurological signs described by Babinski.
\end{abstract}

Key words: Joseph Babinski, Babinski's sign, Babinski's reflex.

\section{Quantos sinais de Babinski existem?}

\section{RESUMO}

Além do famoso sinal descrito por Joseph Babinski, também definido como reflexo de Babinski, existem referências na literatura mundial de vários outros sinais descritos pelo famoso discípulo de J-M Charcot. Este artigo apresenta uma revisão de todos os sinais neurológicos descritos pelo professor Babinski.

Palavras-chave: Joseph Babinski, sinal de Babinski, reflexo de Babinski.

Jean-Martin Charcot (1825-1893), revered throughout the world as the father of clinical neurology, a specialty born in his famous service at the Salpêtrière hospital, had many assistants and colleagues. Among the most prominent were Pierre Marie, Gilles de la Tourette and Joseph Babinski ${ }^{1,2}$.

For many authors Joseph Babinski (Fig 1) was, without a shadow of a doubt, Charcot's favorite pupil. However, because of countless political and institutional problems, Joseph Babinski did not succeed Charcot as the chair of diseases of the nervous system in the Paris Medical School. After the death of his mentor Charcot in 1893 and having failed to climb the academic ladder, Babinski became head of the department of neurology at La Pitié Hospital in Paris, France. In this service he carried out a great number of clinical studies, particularly in the area of neurological semiology, and described various signs of cerebellar syndrome and diseases such as the Babinski-Fröhlich syndrome, as well as the reflex that bears his name and made him famous throughout the world ${ }^{1,3-6}$.

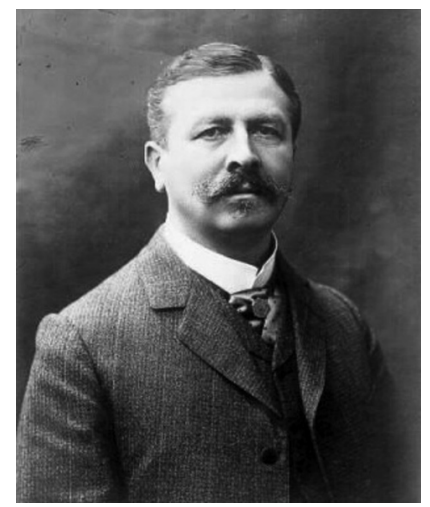

Fig 1. Joseph Babinski. Extracted from http:// commons.wikipedia.org/wiki/Image:Joseph_ Babinski.jpg.

However, Babinski discovered various other neurological signs that now bear his name, and the objective of this paper is to review all the neurological signs that this famous neurologist described.

\section{The protagonist}

The second and last son of the Polish couple Aleksander Babinski and Henryet Weren, who emigrated from Poland to France after the Polish revolution in 1848 , 
Joseph François Felix Babinski was born in Paris on November 17, 1857, two years after Henri Babinski, with whom he lived for most of his life $\mathrm{e}^{3,6,7}$.

In 1879, after completing his basic medical studies, Babinski became a clinical physician at the Hospital Salpêtrière in Paris. During his first years in this position, Babinski combined his duties as a clinical physician with his morphological studies and published a thesis on the pathological anatomy of multiple sclerosis in $1885^{3}$. In the same year, much to his disappointment, his thesis came second in a competition organized by the hospitals of Paris, but he was then appointed head of the neurology clinic in professor Charcot's service even though he had never been his intern. Following that contact, Babinski started to share Charcot's interest in studying different neurological diseases. He used the anatomoclinical method proposed by his master, Charcot, and was particularly interested in discovering ways of distinguishing between the signs and symptoms of hysteria and those of organic neurological conditions.

At the beginning of the 1890s, Babinski left the clinical staff of Salpêtrière Hospital and in 1895 became head of the neurology service at La Pitié Hospital, where he remained until his retirement at the age of 65, 30 years later, after which he only attended the service once a week ${ }^{3,6,7}$.

At La Pitié Hospital, Babinski was responsible for training countless medical students in the field of neurology, whether as residents or externes. These included Cestan, Crouzon, Villaret, Duval, Barre, Meyerson and Clovis Vincent. Various foreign physicians also worked as trainees in Babinski's service, including Wartenberg and Chaddock, from the USA, Samuel Kinnier-Wilson, from the UK, Van Bogaert, from Belgium and Egaz Moniz, from Portugal, the last of these being probably the most famous doctor among Babinski's foreign students ${ }^{3}$.

It should be remembered that Babinski was responsible for establishing the first neurosurgery service in France through his disciple Clovis Vincent ${ }^{3,8}$.

Babinski died on October 29, 1932, at the age of 74, leaving a great contribution to neurology, of which the main legacy was the sign that bears his name $e^{3,6-12}$.

\section{The classic Babinski's sign}

At the Biological Society in Paris in February 1896, at the age of 39, Babinski presented the results of his research into the different responses to stimulation of the sole of the foot in healthy patients, in patients with hemiplegia who had had the disease for several days and in patients with spastic hemiplegia in whom the disease had evolved over several months, with a view to differentiating between organic and psychogenic disorders ${ }^{3,7,9-15}$. The author established a relationship between the extending of the hallux following plantar stimulation (with or with-

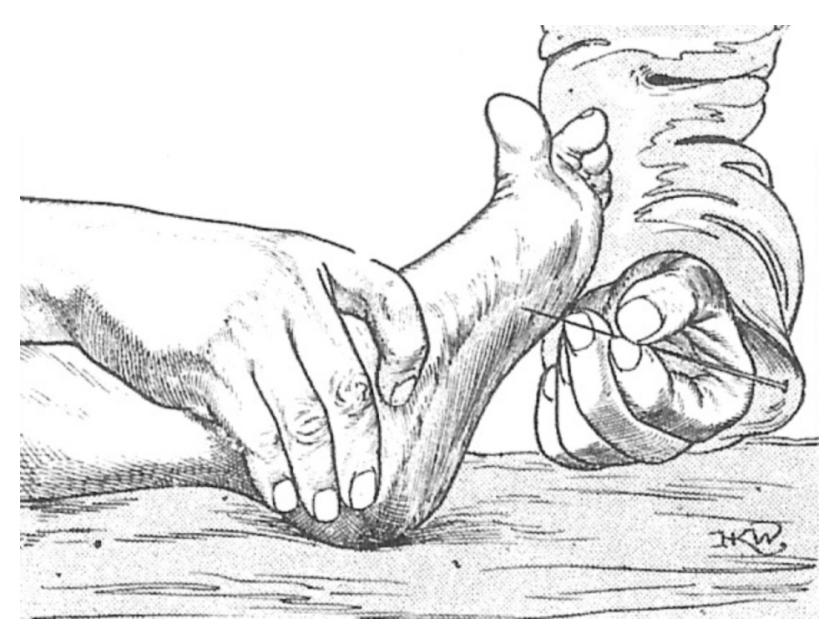

Fig 2. Babinski's sign: Extracted from http://commons.wikipedia. org/wiki/File:Babinski\%27s_sign01.jpg.

out abduction of the other toes) and dysfunction or disease of the pyramidal tract. In comparison, in the healthy patients tested, the response was clearly flexion of the toes (Fig 2) 3,7,9-13,16,17.

In a subsequent communication to the Biological Society, Babinski referred to the extensor plantar skin reflex as the "toe phenomenon"3,11,12,17. In 1898 the Belgian neurologist Arthur Van Gehuchten published the results of his research, which, in addition to supporting Babinski's findings, related the extensor response to the lesion in the pyramidal tract described by Ludwig Türck 46 years earlier. Van Gehuchten also reported that in Belgium this semiological finding was referred to as as the Babinski reflex ${ }^{3,10}$.

Also in 1898, Babinski wrote an improved paper in which he added the following observations: in healthy individuals the hallux may not move after the stimulation; the response may vary depending on the area of the sole of the foot that is stimulated, a greater response being observed if stimulation occurs in the lateral region; and the presence of the sign excludes a diagnosis of hysteria ${ }^{3,11,12,17,18}$.

Five years later Babinski added a new characteristic of the sign: abduction of the toes after the stimulus ${ }^{3,11,12,16-18}$.

Between 1898 and 1907 around 30 articles confirming Babinski's findings were published ${ }^{3}$.

Interesting, the cold stimulation technique for eliciting Babinski's reflex, was evaluated by Gonçalves da Silva and Spina-França in 1966, in a group of 49 patients with diseases of the central nervous system, and the authors concluded that cold stimulation of the plantar region is an useful method of eliciting Babinski's toe phenomenon ${ }^{19}$.

The consistency of the reflex described by Babinski and its variants has been confirmed in different studies in the literature, in particular the study by Singerman and Lee, who evaluated 38 individuals, all of whom were examined by six neurologists, and confirmed that Babinski's sign has a high inter-observer consistency ${ }^{18}$. 
Table. Babinski's rival or "equivalents" signs.

\begin{tabular}{|c|c|}
\hline Sign of & Year \\
\hline Strümpell & 1896 \\
\hline Schaeffer & 1899 \\
\hline Oppenheimer & 1902 \\
\hline Gordon & 1904 \\
\hline Bechterew & 1906 \\
\hline Yoshimura & 1906 \\
\hline Rossolimo & 1908 \\
\hline Chaddock & 1911 \\
\hline Trömner & 1911 \\
\hline Austregésilo \& Esposel & 1912 \\
\hline Pierre Marie \& Meige & 1916 \\
\hline Egaz Muniz & 1916 \\
\hline Bing & 1918 \\
\hline Crafts & 1919 \\
\hline Roch \& Crouzon & 1928 \\
\hline Grünfelder & 1931 \\
\hline Stransky & 1933 \\
\hline Gonda & 1942 \\
\hline Lenggenhager & 1945 \\
\hline Van Thanh & 1973 \\
\hline Hindfelt et al. & 1976 \\
\hline Tashiro & 1986 \\
\hline Hachinski & 1992 \\
\hline Krawczyk & 1996 \\
\hline Berger & 2002 \\
\hline
\end{tabular}

Adapted from refs. 3 and 10.

One hundred and fourteen years after the classic description of the Babinski reflex, this sign continues to be an accurate, consistent indicator of dysfunction of the pyramidal tract ${ }^{3,10-13,16-18}$.

\section{"Equivalents" of Babinski's sign (rival signs)}

Since the classic description of Babinski's sign, various other authors have described the use of different techniques with different excitation sites to detect Babinski's sign, each technique subsequently being given the name of the author who described it ${ }^{3,10}$. Hence, there are more than 30 "equivalents" to or rivals of Babinski's sign ${ }^{3,10}$. Table shows the main substitutes for this sign described to date, the best-known being Chaddock's sign (stroking the skin beneath the lateral malleolus), Oppenheim's sign (stroking the tibial surface) and Gordon's sign (compression of the calf muscle) ${ }^{3,10,20}$. There is even a substitute for Babinski's sign described in 1912 by a Brazilian neurologist that is known as Austregésilo and Esposel's sign (stimulation of the thigh) ${ }^{3,10,21}$.

All these signs are only variations of Babinski's sign and give a clear indication of pyramidal syndrome. ${ }^{3,10,16,19,20}$

\section{Other Babinski's signs}

In addition to the classic sign described by Babinski, there are five other less well-known signs that are also referred to as Babinski's sign. Four of these are described in the Dorland's Medical Dictionary. All five are described below:

[1] Babinski's sign (sciatica/hysteria): Loss or lessening of the Achilles' tendon reflex in sciatica - this distinguishes it from hysterical sciatica. This sign was published in 1896 (Bulletins et Mémoires de la Société Medicale des Hôpitaux de Paris 1896; (XIII): 887-889), as "Abolition du réflexe de tendon d'Achille dans la sciatique" ${ }^{3,22,23}$.

[2] Babinski's sign' (hemiplegia): In hemiplegia, contraction of the platysma muscle in the healthy side is more vigorous than on the affected side, as seen in the opening of the mouth, whistling and blowing (Babinski J. "Sur le spasme du peaucier du cou". Rev Neurol (Paris); 1901(IX):693-696 3,22,24. Leon-Sarmiento et al. published a case with two Babinski's signs (the classic sign and the "platysma" sign) in a female patient with hemiplegia (after a stroke $)^{25}$. In 2008 the same authors published another paper about the presence of two Babinski's signs in patients with tropical spastic paraparesis and called this combination of signs the Babinski plus sign ${ }^{26}$.

[3] Babinski's sign (hemiplegia): When a hemiplegic patient is lying with arms crossed upon the chest and makes an effort to sit up, the thigh on the paralyzed side is flexed upon the pelvis and the heel is lifted from the ground, while on the healthy side the limb does not move ${ }^{3,22,27}$.

[4] Babinski's sign (organic paralysis/hysteria): When the paralyzed forearm is placed in supination, it turns over to pronation: seen in organic paralysis (Pronation sign). (Babinski J. "De la pronation de la main dans l'hémiplégie organique". Rev Neurol (Paris);1907(XV):755 3,22,28.

[5] Babinski's sign (facial hemispasm): With facial hemispasm one may observe a paradoxical raising of the eyebrow during eye closing. (Babinski J. "Hémispasme facial périphérique”. Rev Neurol (Paris); 1905 (XIII): 443$450^{3,22,29}$. In recent years papers about this sign have been published by other authors, such as Devoize in $2001^{30}$ and Stamey and Jankovic in $2007^{31}$.

In conclusion, six signs have been published under the name Babinski's sign. These include the classic Babinski's sign, also known as the toe phenomenon, and five other Babinski's signs: those described in cases of sciatica and hemiplegia, the platysma sign (in hemiplegia), the pronator sign (in hemiplegia) and the Babinski's sign that occurs in hemifacial spasm.

\section{REFERENCES}

1. Goetz CG, Bonduelle M, Gelfand T. Charcot. Constructing Neurology. New York: Oxford University Press, 1995.

2. Teive HAG, Zavala JA, Iwamoto FM, Sa DS, Carraro H Jr, Werneck LC. Contributions of Charcot and Marsden to the development of movement disorders in the $19^{\text {th }}$ and $20^{\text {th }}$ centuries. Arq Neuropsquiatr 2001;59:633-636. 
3. Philippon J, Poirier J. Joseph Babinski. A biography. New York: Oxford University Press, 2009:3-21, 97-131, 151-185, 187-216, 217-248.

4. Massie R. Charcot and Babinski: beyond a simple teacher-student relationship. Can J Neurol Sci 2004;31:422-426.

5. Fine EJ, lonita CC, Lohr L. The history of the development of the cerebellar examination. Semin Neurol 2002;22:375-384.

6. Poirier J. Joseph Babinski: a complex personality. Bull Acad Natl Med 2007;191: 1343-1353.

7. Philippon J. Babinski's legacy. Bull Acad Natl Med 2007;191:1319-1327.

8. Lanzino G, diPiero CG, Laws ER Jr. One century after the description of the "sign": Joseph Babinski and his contribution to neurosurgery. Neurosurgery 1997;40:822-828

9. Gasecki AP, Kwiencinski H. On the legacy of Joseph Babinski. Eur Neurol 1995; 35:127-130

10. van Gijn J. The Babinski sign: a centenary. Universiteit Utrecht, Utrecht, The Netherlands, 1996:17-84.

11. van Gijn J. The Babinski sign: the first hundred years. J Neurol 1996;243:675-683.

12. Rehman HU. Babinski sign. Neurologist 2002;8:316-318.

13. Gasecki AP, Hachinski V. On the names of Babinski. Can J Neurol Sci 1996 23:76-79.

14. Okun MS, Koehler PJ. Babinski's clinical differentiation of organic paralysis from hysterical paralysis: effect on US neurology. Arch Neurol 2004;61:778-783.

15. Oliveira-Souza R, Martignoni de Figueiredo W. O reflexo cutâneo-plantar em extensão. Arq Neuropsiquiatr 1995;53:318-323.

16. Bruno E, Horacio SM, Yolanda $E$, Guillermo GR. The articles of Babinski on his sign and the paper of 1898. Neurol India 2007;55:328-332.

17. Barraquer-Bordas L. What does the Babinski sign have to offer 100 years after its description? Rev Neurol (Paris) 1998;154:22-27.
18. Singerman J, Lee L. Consistency of the Babinski reflex and its variants. Eur J Neurol 2008;15:960-964

19. Gonçalves da Silva, Spina-França A. Sinal de Babinski: emprego de frio como estímulo sensitivo. Arq Neuropsiquiatr 1996:24:180-184

20. Goetz CG. History of the extensor plantar response: Babinski and Chaddock signs. Semin Neurol 2002;22:391-398.

21. Teive HAG, Sá DS, Silveira Neto O, da Silveira AO, Werneck LC. Professor Austregésilo: the pioneer of neurology and of the study of movement disorders in Brazil. Arq Neuropsiquiatr 1999:57:898-902.

22. Dorland's Illustrated Medical Dictionary. $31^{\text {st }}$ Ed. Philadelphia: Saunders, Elsevier, 2007:1733-1734

23. Babinski J. Abolition du réflexe de tendon d'Achille dans la sciatique. Bulletins et Mémories de la Société Medicale des Hôpitaux de Paris 1896:13:887-889.

24. Babinski J. Sur le spasme du peaucier du cou. Rev Neurol (Paris) 1901;9:693-696.

25. Leon-Sarmiento FE, MontoyaMC, Camacho JE, Bayona-Prieto J, Bayona E. Hemiplegia with two Babinski's sign. Medicina (B Aires) 2007;67:374-376.

26. Leon-Sarmiento FE, Calderon A, Hernandez HG. Two Babinski signs in seropositive (HAM) and seronegative tropical spastic paraparesis. Arq Neuropsiquiatr 2008;66:695-697.

27. Babinski J. Diagnostic différentiel de I'hémiplégie organique et de I'hémiplégie hystérique. Gaz Hôp 1900;73:533-537.

28. Babinski J. De la pronation de la main dans l’hémiplégie organique. Rev Neurol (Paris) 1907;15: 755

29. Babinski J. Hémipasme facial périphérique. Rev Neurol (Paris) 1905;13:443-450.

30. Devoize JL. "The other" Babinski's sign: paradoxical raising of the eyebrow in hemifacial spasm. J Neurol Neurosurg Psychiatry 2001;70:516.

31. Stamey W, Jankovic J. The other Babinski sign in hemifacial spasm. Neurology 2007;69:402-404 